\title{
The U.S. Labor Relations System after Janus v. AFSCME: an Early Assessment
}

\author{
Ann C. Hodges ${ }^{1}$
}

Accepted: 9 December 2020 / Published online: 15 January 2021

(C) The Author(s), under exclusive licence to Springer Science+Business Media, LLC part of Springer Nature 2021

\begin{abstract}
In 2018, anti-union organizations accomplished one of their top goals by convincing the U.S. Supreme Court to overturn 40 years of precedent and declare union security clauses in the public sector unconstitutional. Many predicted such a decision would lead to the end of public sector unions, but thus far that has not occurred. Nor has the labor relations system, of which these fees were an integral part, crumbled. This article looks at what has happened in the two years since the decision came down, including the continuing efforts to deprive unions of membership and funding, and the union responses. The article also looks at other recent trends in labor relations - a significant uptick in the number of strikes and the growth of social movement unionism. The trends provide hints that the country may be on the cusp of a transformative moment in labor relations. Significant questions remain, however, about what the future will bring.
\end{abstract}

Keywords Union security · Right to work · Exclusive representation · Union dues · Union organizing $\cdot$ Strikes $\cdot$ Social movement unionism $\cdot$ Police unions

\section{Introduction}

In 2016, in this journal, I imagined what labor relations would look like in the United States without union security (Hodges 2016). While union security has not been completely abolished, the campaign to eliminate it succeeded in one of its major goals in 2018. The Supreme Court in Janus v. AFSCME, reversing over 40 years of precedent, outlawed union security in the public sector (Janus 2018). As a result, unions representing government employees must now provide representation to all employees in the bargaining unit but cannot compel payment for that representation from any employee that chooses not to support the union financially. In this article, I look at what has happened to labor relations, unions, and the law since Janus. While it

Ann C. Hodges

ahodges@richmond.edu

1 School of Professional \& Continuing Studies, University of Richmond, 490 Westhampton Way, Richmond, VA 23173, USA 
is early to assess the full impact of the decision, both unions and the forces opposed to them anticipated the decision and began taking steps to prepare well before the decision came down.

Preliminary observations suggest a few trends. Some new laws have emerged at the state level to protect and encourage unionization. Unions have adapted some tactics and strategies to respond to new realities. There has been some resurgence of resistance on the part of workers, although other factors such as the coronavirus pandemic and state budget cuts have been primary contributors to this trend. Legal challenges to the exclusive representation model are in process, although so far unsuccessful. And finally, the efforts to decimate unions continue, with multiple lawsuits to recover dues and fair share fees lawfully collected pre-Janus. Thus far, there have not been major changes to the labor relations system or its actors. The increase in employee resistance in both the public and private sectors and even in states without collective bargaining rights for public employees may suggest that the deunionization of the U.S. workforce has hit bottom. But the forces arrayed against unions are powerful and the win in Janus has fueled their efforts. The future of labor relations in the U.S. remains uncertain.

This essay will begin with a brief review of the current labor relations system in the U.S. and the decision in Janus v. AFSCME. That will be followed by an analysis of the post-Janus tactics of the anti-union forces, including the litigation prompted by the decision, and the impact on unions. The essay will then move to union responses, including increased organizing and legislation enacted at the state level. Finally, the essay will review other developments in labor relations such as the resurgence of the strike and the rise of social movement unionism, concluding with the current divisions in the labor movement relating to police unions. Each of these developments provides hints about the future of labor relations and unions, but much is yet to be written.

\section{The U.S. Labor Relations System and Janus}

As detailed in the earlier article, the U.S. system of labor relations is based on exclusive representation. A union, chosen by at least a simple majority of employees in an appropriate bargaining unit, represents all the workers in that unit. The employer must deal exclusively with the union chosen by the majority, and the union must represent all the employees in the unit fairly and in good faith. A union security clause, negotiated by the employer and the union as a part of the collective bargaining agreement, permits the union to charge a fee for representation to those who do not want to join the union and pay full union dues. Section 14(b) of the National Labor Relations Act (n.d) allows states to enact laws, colloquially and often confusingly known as right-to-work laws, that prohibit negotiation of such clauses (NLRA, Section 14(b)). As of 2020, twenty-seven states had enacted such laws. (National Conference of State Legislatures 2020). While most of these laws were passed in the mid-twentieth century, anti-union forces succeeded in adding six states to the total since 2012, including the important Rust Belt states of Indiana, Michigan and Wisconsin (National Conference of State Legislatures 2020; Bales 2020, 7).

Like the NLRA, most state collective bargaining laws also allowed collection of fees for representation, often denominated as fair share fees, except in those states with right-to-work laws. In 1977, the Supreme Court upheld fair share fees as against constitutional challenge in Abood v. Detroit Board of Education (Abood 1977), but in 2018, after decades of effort, the organizations and individuals opposed to unions succeeded in convincing the Supreme Court 
to reverse Abood and hold that fair share fees for government employees violate the First Amendment (Janus 2018, 2460). Nothing really changed between Abood and Janus but the Court. Reconsidering Abood, the Court majority concluded that collecting such fees impaired the free speech rights of employees compelled to support the union, even when the fees were used only to support collective bargaining and contract administration (Janus 2018, 2460-61, 2464). Rejecting the distinction that Abood made between the union's political speech and collective bargaining and contract administration, the Court emphasized that public sector bargaining is "inherently political" (Janus 2018, 2458). The Court went on to find, contrary to the Abood Court, that the interests in labor peace and stability and avoiding free riders (those who benefit from union representation without paying for it) did not justify the infringement on speech rights (Janus 2018, 2466, 2469). The decision invalidated thousands of collective bargaining agreements in multiple states, all negotiated in reliance on the Court's earlier decision in Abood and valid state laws enacted in accord with that decision (Janus 2018, 2499).

\section{Post-Janus Efforts to Reduce Union Power}

The forces that have long funded the litigation challenging union finances ${ }^{1}$ immediately went to work to take advantage of the decision to both recoup previously paid dues and fees and to convince employees to withdraw their membership from unions. In addition, they have filed lawsuits challenging related aspects of the labor relations system.

\section{Efforts to Recover Dues and Fees}

Hundreds of cases have been filed against unions which collected fair share fees under state laws that were invalidated by Janus. If successful, the claims would require unions to refund millions of dollars of fees collected when authorized by state laws and already spent representing members (Hodges 2020, 4). The cases have been filed in many different jurisdictions based on a variety of legal theories, but primarily seek retroactive application of Janus (Hodges 2020, 4-5). They have been singularly unsuccessful thus far, but impose substantial litigation costs on unions that could otherwise dedicate these resources to representing workers (Hodges 2020, 6-9). Courts considering the issue have determined that unions have a good faith defense to such claims because they collected the fees in reliance on validly enacted state laws which had been declared constitutional by the Supreme Court in 1977 (Hodges 2020, 6-9). Regardless of how one feels about unions and fair share fees, these cases have troubling implications. While thus far unions have prevailed, a contrary result would mean that a private party could be liable for millions of dollars for conduct that is not only explicitly authorized by state law but also state law that has previously been found constitutional by the highest court in the land. The plaintiff in Janus lost his case seeking to recoup his fees and has a petition for certiorari pending at the Supreme Court. Some have suggested that Justice Ginsburg's death and likely replacement by a far more conservative justice might lead to another decision favoring union opponents in the fee repayment cases (Campbell 2020).

\footnotetext{
${ }^{1}$ Although the identity of some of the funders of this litigation and related efforts to convince employees to cease supporting unions is hidden, some information has been uncovered. (Schrieber \& Vogel 2018; Urevich 2019).
} 
Other cases have sought to recover union dues paid by employees who voluntarily joined unions prior to Janus. The employees argue that they joined the union because the difference between union dues and fees was small and they chose membership in order to be able to access benefits available to members, for which fee payers were ineligible (Hodges 2020, 11). Accordingly, these employees claim that they would not have joined the union if they were not otherwise required to pay fees for representation (Hodges 2020,11.) Again, courts have rejected the cases, both based on the good faith defense and because these employees voluntarily joined the union and accepted the benefits of that membership (Hodges 2020, 11). They cannot now be heard to complain.

A similar claim attempts to invalidate union members' signed authorizations that request the employer to deduct their union dues from their pay and remit them to the union (Hodges 2020,11 ). These authorizations typically are in effect for a specified time period (Hodges 2020, 11). Employees have sought untimely revocation post-Janus, again arguing that they would not have joined the union and executed these authorizations had they not been required to pay fees (Hodges 2020,11). The courts have rejected these claims on the same grounds the employees voluntarily chose to join the union, authorize dues deduction, and accept the benefits of membership (Hodges 2020, 12).

\section{Efforts to Convince Employees to Abandon their Unions}

In addition to legal challenges, organizations opposing unions have engaged in campaigns to convince employees to cease supporting their unions (Patrick 2019). These groups contact union members by mail and email and hire paid staff to visit workers on the job and at home, all to inform them about Janus and convince them to drop their union membership (Patrick 2019). The organizations have used phone calls and billboards, along with Facebook and television ads, to tell employees that they need not pay union dues (Kamenetz 2018). While the groups engaged in this activity frame their campaign as one of freedom and individual rights, their sales pitch to the workers is often financial, about saving the money paid to the union while retaining the benefits of union representation (Kamenetz 2018).

\section{Private Sector Union Security}

Union security in the private sector is less vulnerable to constitutional challenge than in the public sector. There is serious doubt whether legislation which merely allows, but does not encourage, two private parties-unions and employers-to agree to union security provisions constitutes sufficient government action to implicate the First Amendment (Slater 2017). Indeed, the Janus majority emphasized the difference between the private sector and public sector (Janus 2018, 2458). But in the earlier case of Harris v. Quinn, as Professor Joseph Slater has pointed out, the majority seemed open to the argument that private sector union security agreements violate the First Amendment (Slater 2017, 62-63). There is no doubt that the funders of the lawsuits that eliminated public sector union security will make every possible effort to eliminate union security in the private sector as well, whether through litigation or legislation.

\section{Post-Janus Challenges to Exclusive Representation}

Post-Janus litigation not only seeks to recoup payments made to unions before invalidation of agency fee laws. The organizations funding challenges to union dues and fees have also 
targeted the entire system of exclusive representation. In Janus, the majority stated in dicta that "[i]t is also not disputed that the State may require that a union serve as exclusive bargaining agent for its employees - itself a significant impingement on associational freedoms that would not be tolerated in other contexts" (Janus 2018, 2478). This language gave union opponents an opening to argue that exclusive representation violates employees' right to freedom of association by forcing them to be represented by a union they do not desire. Thus far these challenges have been unsuccessful, as courts have relied on earlier Supreme Court precedent rejecting a First Amendment challenge to exclusive representation (Hodges 2020, 12-13). As Janus proves, however, the Court is not always reluctant to overturn precedent and it remains to be seen whether these arguments will gain traction in the future. The death of Justice Ginsburg and the probable shift of the Court to the right with her replacement may make a successful challenge to excusive representation more likely (Campbell 2020).

\section{The Impact of Janus on Union Membership and Finances}

Predictions regarding the impact of Janus on union membership and finances varied, with some posing doomsday scenarios and others suggesting a more modest impact (Tang 2019, 695-700). While organizations seeking to persuade employees to drop out of unions claim some successes (Kamenetz 2018), data suggest relatively modest effects thus far. Reports, including one from the conservative Manhattan Institute, indicate that while fee payers have been eliminated, union membership has increased in some places (DiSalvo 2019, 4; Rainey and Kullgren 2019; Reyes 2019). Overall, union membership in the public sector dropped by .3\% between 2018 and 2019, from $33.9 \%$ of employed workers to $33.6 \%$ (BLS 2020). Nor does early evidence suggest substantial financial losses (Rainey and Kullgren 2019; Reyes 2019). How did unions stave off the potential massive losses that some predicted would result from Janus?

\section{Union Responses to Janus}

The decision in Janus was not unpredictable (Greenhouse 2020, 339). Justice Alito laid the groundwork for overturning the decision in two earlier cases, inviting a case that would provide an opportunity to overturn Abood (Greenhouse 2020, 342-46; Knox 2012, 314; Harris 2014, 633-38). An earlier case seeking that result failed after Justice Scalia died while the case was pending in the Court (Greenhouse 2020, 344). The Senate refused to hold a hearing on President Obama's nominee to replace Justice Scalia and accordingly, his replacement was appointed by President Trump in 2017. Given the makeup of the Court and the signals from earlier opinions, unions began to prepare for elimination of fair share fees. Unions employed several strategies to meet the challenge of Janus. Unions have expanded internal organizing among their members, successfully pushed for enactment of state laws to aid their efforts to maintain membership, and developed allies among the public by focusing on issues of mutual interest.

\section{Internal Organizing}

In anticipation of Janus, unions began to increase outreach to members using workplace conversations, home visits, newsletters, text messages, and mobile phone apps (Hodges and 
Malin 2020, 67). Additionally, unions prioritized meeting with new employees to educate them about the union. The outreach was designed to obtain, engage, and reengage members, determining their priorities in order to more effectively meet their needs (Hodges and Malin 2020, 67). In addition to listening to the members and educating them about union activities, unions formed membership action teams and employed direct actions to build solidarity and press member priorities (Hodges and Malin 2020, 67). These activities have included rallies, press conferences, distribution of literature, informational pickets and attendance at public meetings (Hodges and Malin 2020, 67). As just one example, in Virginia, long a right-to-work state, a transit union increased its membership by 200 members, achieving an $85 \%$ membership rate using these tactics (Ertl 2017).

\section{New Legislation}

In states where public sector unions have sufficient political power, they have sought and obtained legislation designed to facilitate internal organizing, maintain finances, and combat efforts to persuade members to leave their unions. Connecting with employees at the beginning of their employment makes union membership more likely and increases commitment in those who join (Wasser 2016, 3, 5). For example, the California Association of Highway Patrol conducts a union orientation process when officers graduate from the academy, resulting in a 97\% membership rate (Ashton 2017). Several states have enacted legislation providing unions with information about new employees and access to new employees during orientation (Fisk and Malin 2019, 1872-73). These laws require employers to provide unions with notice of employee orientations and an opportunity to meet with employees outside the presence of supervisors (Fisk 2020, 347-48). To facilitate access, unions have sought, and in some cases obtained, legislation authorizing use of the employer's email system for union communications, along with detailed information about employees in the bargaining unit (N.J. Stat. Ann. $\S$ 34:13A-5.13 2018). While increasing their own access to information, unions have supported legislation to prevent release of employee contact information to outside organizations, in order to limit the ability of anti-union forces to contact the employees (Cal. Government Code $\S 6254.32017)$.

Other recent legislation is designed to protect union finances. A New Jersey law prohibits employers from encouraging employees to abandon the union or cease payroll deduction of dues (N.J. Stat. Ann. $\S 34: 13$ A-5.14 2018). New York law provides for payroll deduction of dues upon employee authorization and allows unions to use the authorization to define the terms under which revocation of the authorization is permissible (N.Y. Civ. Serv. Law $\S \S$ 93-b, 201, 208, 209-a 2017). Several other states have similar provisions, while New Jersey and Hawaii limited revocation periods by statute (Fisk and Malin 2019, 1858-59).

Finally, New York and Rhode Island joined several other states with laws allowing unions to decline representation of nonmembers, where those employees have a right to represent themselves in the grievance process (Fisk and Malin 2019, 1837-40). New York's law permits the union to refuse representation in administrative proceedings regarding discipline and in disciplinary interviews also (Fisk and Malin 2019, 1840). Nebraska and Nevada allow unions to charge nonmembers for representation in the grievance process (Fisk and Malin 2019, 1839). Each of these states maintains the requirement that unions fairly represent nonmembers in negotiations. The Court in Janus suggested that this distinction would be a way to protect the union's interests with less burden on employees' speech rights (Janus 2018, 2468-69). 
This legal trend has the potential to erode the existing labor relations system, which is based on exclusive representation. Many unions have resisted the temptation to move toward members only representation, however, for several reasons. Representation of a nonmember in a grievance proceeding may convince the individual of the value of the union, turning a nonmember into a supporter. In addition, the union loses the ability to exert some control over the interpretation of the contract when individuals can represent themselves in the grievance and arbitration process (Fisk and Malin 2019, 1843-44). The resulting decision may harm other workers (Fisk and Malin 2019, 1843-44). Further, evidence does not suggest that allowing unions to charge nonmembers for representation in the grievance process increases membership in the union in most cases, although it may conserve existing union resources for the use of members (Fisk and Malin 2019, 1840-42). The absence of exclusive representation can weaken the union as well, enabling the use of divide and conquer tactics by employers and union opponents (Brooks 2017). And some labor advocates fear that ending exclusive representation and the accompanying duty of fair representation might enable discrimination (Bronfenbrenner et al. 2018).

Representing only members has some appeal, however. Competing unions in a workplace may lead to better representation (Bronfenbrenner et al. 2018). Representing only members eliminates the problem of free riders and the resentment of members who must pay for representation for nonmembers (Brooks 2017). A legal challenge by one union claims that forcing it to represent nonmembers who oppose the union violates the First Amendment speech rights of the Union and its members (Sweeney 2018, Para. 24). The case is still pending, and like the cases attacking exclusive representation brought by union opponents, it poses a challenge to the existing system of labor relations (Sweeney 2019).

\section{Related Developments in Labor Relations}

\section{Increased Strikes and Social Movement Unionism}

While the relationship to Janus is not direct, other developments in labor relations since 2016 may provide some signposts for the future. The use of the strike declined significantly beginning in the 1970s (Shierholz and Poydock 2020). Many observers attribute the continued decline to President Reagan's firing of the air traffic controllers in response to the PATCO strike in 1981, and the subsequent increase in employer use of replacements and lockouts (Dau-Schmidt et al. 2019, 776). The trend reversed in 2018 and 2019, however, led by massive unlawful teachers' strikes in states without collective bargaining laws (Dau-Schmidt et al. 2019, 776). These strikes followed years of decreases in state funding for education and they focused not only on teacher pay, but also on improved funding for classrooms, books, and other school staff (Dau-Schmidt et al. 2019, 1-2, 197). Union membership increased in states where walkouts occurred despite right to work laws (Semuels 2018). Thus far in 2020, scores of strikes have occurred in response to Covid-19 and in support of the Black Lives Matter movement, many of them wildcat strikes (Brecher 2020b; Brecher 2020c). In many cases, the workers are striking without the support of unions, either because they are not unionized or because their union does not support the strike (Elk 2020). In other strikes, the workers have continued to strike after the union has recommended a return to work (Dau-Schmidt et al. 2019 , 197). Some recent strikes use unique tactics, such as getting small businesses to shut down to support the strike (Elk 2020). 
In addition to the renaissance of strike activity, social movement unionism is growing. Unions, particularly in the public sector, are focusing on collaborative partnerships with other organizations and with the people they serve. Teachers' strikes have focused on the quality of public education, seeking increased funding for schools with support of parents (Yan 2018). An organization supporting these partnerships is Bargaining for the Common Good, a coalition of community organizations and public sector unions that describes itself as follows: "Unions that have the right to bargain use contract fights as an opportunity to organize with community partners around a set of demands that benefit not just the bargaining unit, but also the wider community as a whole" (Bargaining for the Common Good, About Us 2020).

Teachers in St. Paul, for example, have a long history of negotiating for the common good, including smaller class sizes, mental health teams for each school, more multilingual staff, more school nurses, and lighter loads for special education teachers (Verges 2020). It is not only public sector unions that bargain for the common good, however. SEIU Local 26 in Minnesota, which represents cleaning workers, negotiated for green cleaning as well as a table of building owners and community groups to address environmental issues (Brecher 2020a). The union even engaged in a one-day strike, supported by community environmental organizations, in support of their demands (Brecher 2020a). Another recent example not directly tied to the Bargaining for the Common Good organization is the Milwaukee Bucks players' one game strike in response to the shooting of Jacob Blake and the protests in Kenosha, just down the road from Milwaukee (Jones and Danner 2020). The strike, which was joined by players in other professional sports, led to creation of a coalition by the NBA owners and players to address social justice issues, including "access to voting, promoting civic engagement and advocating for meaningful police and criminal justice reform" (Jones and Danner 2020). The move of traditional unions towards social movement unionism coincides with the development of alternative labor organizations which engage in worker advocacy without seeking exclusive representation rights (Hodges 2016, 139). Funding remains a problem for these alternative groups without dues and fees to support their activities, however (Hodges 2016, 139).

These recent developments, some in response to crises in our country, suggest that unionism and labor relations may be changing as a result of the activism of young people. These activists view unions as just another vehicle for social justice and organizing for labor rights, human rights, civil rights, immigrant rights and climate justice as interrelated. Organizers may move between organizations with related objectives, or hold dual positions. Several union officials from the SEIU, which has partnered with other organizations for climate justice, have moved from the union to organizations focused on climate justice and worker innovation (How Strikes 2020). Another example is Jess Morales Rocketto who serves with the National Domestic Workers Alliance, while co-chairing the Families Belong Together Coalition which works "to end family separation and detention," after also serving with the AFL-CIO and in several political campaigns (National Domestic Workers Alliance 2020).

The increased activism is reflected in data regarding support for unions, particularly among young people. Unions have one of the highest approval ratings in the last fifty years according to the Gallup poll, and their approval among young people aged 18-34 is the highest of any age group (Jones 2019). A recent study of students attending public colleges in Los Angeles County and also working at the same time found that $85 \%$ would join a union or a worker center if given the opportunity, as compared to $59 \%$ in a similar survey in 2015 (UCLA 2020, 29). Sixty-one percent had increased their involvement in organizing and $59 \%$ increased their involvement in electoral politics since Covid-19 (UCLA 2020, 27). While the study's participants may not be reflective of the general population, the results reflect the reality that there 
are many young activists who see unions as a tool for social justice and who have been motivated by the pandemic and police killings of African-Americans to increase their activism. Despite these developments, however, it would be a mistake not to recognize the very real challenges faced by the labor movement.

\section{The Challenge Posed by Police Unions}

Potential fissures in the labor movement relating to police unions present a challenge and perhaps portend future changes as well. Recent literature has identified police unions as obstacles to the reduction and elimination of structural racism in policing (Hardaway 2019, 172-93; Rushin 2019, 570-88). As the protests erupted after the killing of George Floyd, public pressure focused on the unions as well. Activists, within unions and outside, urged labor federations to expel police unions (Cunningham-Cook 2020). Some responded and some declined (Rainey and Otterbein 2020). The AFL-CIO headquarters in Washington was vandalized by protesters (Gangitano 2020).

Proposals for reform emerged, some focused on eliminating police unions altogether and others on limiting their authority to negotiate protections and grieve and arbitrate disciplinary actions (Fisk et al. 2020; NAACP LDF 2020, 9-10). Opponents of public sector bargaining have seized the opportunity to argue that bargaining should be outlawed for all public employees as all public employee unions are against the public interest (Cunningham-Cook 2020). Still others have contended that police unions could be part of the solution. (Malin and Slater 2020). The impact of the movement for racial justice has the potential to divide the labor movement, or to bring together coalitions of unions and other organizations dedicated to racial justice to work towards a common goal, or both.

\section{Conclusion}

Janus is only one of the potential disrupters of the existing labor relations system in the United States. The country is presently in an era with conditions very similar to that which preceded the passage of the National Labor Relations Act (n.d.), creating our current system. The economy is undergoing a significant change, from a manufacturing base to a service and technology base. Income inequality is reaching heights not seen since the years immediately preceding the Great Depression (Sommeiller and Price 2018). We are in a significant economic crisis, although it has not reached the severity of the Depression. The country is also in a period of public unrest, with ongoing protests, some involving violence. Both employers and unions are critical of the current labor laws, and proposals for change abound. Similar conditions led to the creation of the current system, and the establishment of the labor movement as an institution in the United States.

The U.S. labor movement adopted the philosophy of business unionism. Young activists in the labor movement today are fueling the trend toward a movement focused on social justice. They are pushing and pulling unions in that direction. The Janus decision may be furthering these efforts by prompting unions to intensify engagement with their membership and to develop partnerships with other organizations. These disruptions make predictions of the future difficult. Scholars and practitioners of labor relations have important roles to play in this story. We should carefully consider what we want the future of U.S. labor relations to be and the role that we can play in shaping it. 


\section{Compliance with Ethical Standards}

Conflict of Interest The author declares that she has no conflicts of interest.

Human Participants or Animals Performed The article does not contain any studies with human participants or animals performed by the author.

Informed Consent There were no individual participants in this study and, thus, informed consent does not apply to this study.

\section{References}

Abood v. Detroit Board of Education (1977), 431 U.S. 209.

Ashton, A. (2017). Everything is at stake: California unions brace for a supreme court loss. Sacramento Bee (Oct. 24). Online at https://www.sacbee.com/news/politics-government/the-state-worker/article180426706. html. Accessed 26 Sept 2020.

Bales, R. (2020). Union trends. In Bales, R. \& Garden, C. (eds.) The Cambridge Handbook of U.S. Labor Law for the Twenty-First Century (pp. 3-11). Cambridge University Press.

Bargaining for the Common Good, About Us. Online at https://www.bargainingforthecommongood.org/about/. Accessed 21 Sept 2020.

Brecher, J. (2020a). Did we just witness the first union-authorized climate strike in the United States? Common Dreams (March 1). Online at https:/www.commondreams.org/views/2020/03/01/did-we-just-witness-firstunion-authorized-climate-strike-united-states. Accessed 21 Sept 2020.

Brecher, J. (2020b). Striking in the coronavirus depression. Labor Network for Sustainability (September 2). Online at https://www.labor4sustainability.org/strike/striking-in-the-coronavirus-depression/. Accessed 21 Sept 2020.

Brecher, J. (2020c). Workers v. the coronavirus depression. Labor Network for Sustainability (September 17). Online at https://www.labor4sustainability.org/strike/workers-vs-the-coronavirus-depression/. Accessed Sept. 21, 2020.

Bronfenbrenner, K., Brooks, C., \& Richman, S. (2018). After Janus, should unions abandon exclusive representation. In These Times (May 25). Online at https://inthesetimes.com/article/janus-unions-exclusiverepresentation-labor-right-to-work-supreme-court. Accessed 27 Sept 2020.

Brooks, C. (2017). The cure worse than the disease: Expelling freeloaders in an open-shop state. New Labor Forum. Online at https://newlaborforum.cuny.edu/2017/08/24/the-cure-worse-than-the-disease/. Accessed 23 Sept 2020.

Bureau of Labor Statistics (2020). Table 3. Union affiliation of employed wage and salary workers by occupation and industry. Bureau of Labor Statistics (January 22). Online at https://www.bls.gov/news.release/union2. t03.htm. Accessed 20 Sept 2020.

Campbell, B. (2020). 4 employment issues in play for a more conservative court. Employment Law 360 (September 22). Online at https:/www.law360.com/employment/articles/1312534/4-employment-issuesin-play-for-a-more-conservative-court?nl_pk=05bb4d59-4494-4f64-8a01-c5427830a567\&utm_source= newsletter\&utm_medium=email\&utm_campaign=employment. Accessed 20 Sept 2020.

Cunningham-Cook, $\bar{M}$. 2020. The AFL-CIO's police union problem is bigger than you think. The Intercept (June 18). Online at https://theintercept.com/2020/06/18/afl-cio-police-labor-union/. Accessed 21 Sept 2020.

Dau-Schmidt, K., Malin, M., Corrada, R., Cameron, C., \& Fisk, C. (2019). Labor law in the contemporary workplace (3d. ed.). St. Paul: West Academic Publishing.

DiSalvo, D. (2019). Public-sector unions after Janus: An update, The Manhattan Institute (February). Online at https://www.manhattan-institute.org/public-sector-unions-after-janus. Accessed 19 Sept 2020.

Elk, M. (2020). How black and brown workers are redefining the strike in the digital covid age. PayDay Report (July 8). Online at https://paydayreport.com/how-black-brown-workers-are-redefining-strikes-in-a-digitalcovid-age/ Accessed 21 Sept 2020.

Ertl, J. (2017). Vigorous campaign revives transit union in right-to-work Virginia. Labor Notes (May 31) Online at https://labornotes.org/2017/05/vigorous-campaign-revives-transit-union-right-work-virginia. Accessed 26 Sept 2020.

Fisk, C. (2020). Union security for the twenty-first century. In: Bales, R. \& Garden, C. (eds.) The Cambridge handbook of U.S. labor law for the twenty-first Century (pp. 336-50). Cambridge University Press.

Fisk, C., \& Malin, M. (2019). After Janus. California Law Review, 107, 1821-1876. 
Fisk, C., et al. (2020). Reforming law enforcement labor relations. California Law Review Blog (August) Online at http://www.californialawreview.org/reforming-law-enforcement-labor-relations/. Accessed 21 Sept 2020.

Greenhouse, L. (2020). The supreme court's challenge to civil society. Supreme Court Review, 8, 335-353.

Hardaway, A. (2019). Time is not on our side: Why specious claims of collective bargaining rights should not be allowed to delay police reform efforts. Stanford Journal of Civil Rights and Civil Liberties, XV, 137-99.

Harris v. Quinn (2014), 573 U.S. 616.

Hodges, A. (2020). The aftermath of Janus v. AFSCME: An ongoing assault on public sector unions, American Constitution Society Issue Brief (March). Online at https://www.acslaw.org/issue_brief/briefs-landing/theaftermath-of-janus-v-afscme-an-ongoing-assault-on-public-sector-unions/

Hodges, A. (2016). Imagining U.S. labor relations without union security. Employee Responsibilities and Rights Journal, 28, 135-145.

Hodges, A. \& Malin, M. (2020). Public sector innovations. In Bales, R. \& Garden, C. (eds.) The Cambridge Handbook of U.S. Labor Law for the Twenty-First Century (pp. 64-74). Cambridge University Press.

How Strikes and Community Coalitions Can Address the Crises We Are Facing (2020), Webinar, (April 20). Online at https://www.youtube.com/watch?v=tuZrbzv0A3E\&feature=youtu.be Accessed Sept. 21, 2020.

Janus v. Am. Fed'n of State, Cty., \& Mun. Employees, Council 31 (2018), 138 S. Ct. 2448, 2458, 2460, 2460 61, 2464, 2466, 2468-69, 2469, 2478, 2499.

Jones, J. (2019). As Labor Day turns 125, union approval near 50 year high. Gallup News (August 28). Online at https://news.gallup.com/poll/265916/labor-day-turns-125-union-approval-near-year-high.aspx. Accessed 28 Sept 2020.

Jones, S. \& Danner, C. (2020). NBA playoffs will resume, league and players announce new social justice initiatives. New York Intelligencer (Aug. 28). Online at https://nymag.com/intelligencer/2020/08/nba-teamsstrike-for-black-lives.html. Accessed 21 Sept 2020.

Kamenetz, A. (2018). Behind the campaign to get teachers to leave their unions. NPR (July 19). Online at https:// www.npr.org/sections/ed/2018/07/19/628130197/behind-the-campaign-to-get-teachers-to-leave-theirunions. Accessed 21 Sept 2020.

Knox v. SEIU Local 1000 (2012), 567 U.S. 298.

Malin, M. \& Slater, J. (2020). In defense of police collective bargaining. Chicago Sun Times (August 12). Online at https://chicago.suntimes.com/2020/8/12/21365763/chicago-police-fop-collective-bargaining-rights. Accessed 24 Sept 2020.

N.J. Stat. Ann. § 34:13A-5.13 (2018).

N.Y. Civ. Serv. Law $\S \S 93-b, 201,208,209-a(2017)$.

National Conference of State Legislatures, Right-to-Work Resources. National Conference of State Legislatures. Online at https://www.ncsl.org/research/labor-and-employment/right-to-work-laws-and-bills.aspx Accessed Sept. 18, 2020.

National Domestic Workers Alliance (2020). Spokespersons, Jess Morales Rocketto. National Domestic Workers Alliance. Online at https://www.domesticworkers.org/spokespersons. Accessed 26 Sept 2020.

National Labor Relations Act, (n.d.) Section 14(b), 29 U.S.C. Section 164(b).

Patrick, K. (2019). One year after Janus, conservatives begin difficult campaign to tackle union embership. Inside Sources: Politics (July 8). Online at https:/www.insidesources.com/one-year-after-janus-laborgroups-say-public-sector-unions-are-doing-fine/. Accessed 26 Sept 2019.

Rainey, R. \& Kullgren, I. (2019). 1 year after Janus, unions are flush, Politico (May 17). Online at https://www. politico.com/story/2019/05/17/janus-unions-employment-1447266. Accessed 20 Sept 2020.

Rainey, R. \& Otterbein, H. (2020). Local unions defy AFL-CIO in push to oust police unions. Politico (June 30). Online at https:/www.msn.com/en-us/news/world/local-unions-defy-afl-cio-in-push-to-oust-police-unions/ ar-BB16aShF. Accessed 21 Sept 2020.

Reyes, J. (2019). One year out, how has the Supreme Court's 'Janus' decision affected Pa. and N.J. unions? The Philadelphia Inquirer, (July 1). Online at https:/www.inquirer.com/news/pennsylvania-new-jersey-unionsjanus-impact-fair-share-20190701.html. Accessed 22 Sept 2020.

Scheiber, N. \& Vogel, K. (2018). Behind a key anti-labor case, a web of conservative donors, N.Y. Times (Feb. 25). Online at https://www.nytimes.com/2018/02/25/business/economy/labor-court-conservatives. html\#: :text=Behind $\% 20$ a\%20Key $\% 20$ Anti-Labor $\% 20 \mathrm{Case} \% 2 \mathrm{C} \% 20 \mathrm{a} \% 20 \mathrm{Web} \% 20$ of,on $\% 20$ the $\%$ 20case\%20after\%20Justice\%20Antonin\%20Scalia\%E2\%80\%99s\%20death. Accessed 18 Sept 2020.

Semuels, A. (2018). Is this the end of public-sector unions in America? The Atlantic (June 27). Online at https:// www.theatlantic.com/politics/archive/2018/06/janus-afscme-public-sector-unions/563879/. Accessed 27 Sept 2020.

Shierholz, H. \& Poydock, M. (2020). Continued surge in strike activity signals worker dissatisfaction with wage growth. Economic Policy Institute (February 11). Online at https://www.epi.org/publication/continuedsurge-in-strike-activity/. Accessed 23 Sept 2020. 
Slater, J. (2017). Will labor law prompt conservative justices to adopt a radical theory of state action? Nebraska Law Review, 96, 62-99.

Sommeiller, E. \& Price, M. (2018). The new gilded age. Economic Policy Institute (July 19). Online at https:// www.epi.org/publication/the-new-gilded-age-income-inequality-in-the-u-s-by-state-metropolitan-area-andcounty/. Accessed 24 Sept 2020.

Sweeney v. Rauner (2018). No. 1:18-cv-01362, Complaint (N.D. Ill.).

Sweeney v. Madigan (2019). 359 F. Supp. 3d 585 (N.D. Ill.), appeal docketed, Sweeney v. Raoul, No. 19-3413. Tang, A. (2019). Life after Janus. Columbia Law Review, 119, 677-761.

UCLA Labor Studies, UCLA Labor Center \& UCLA Institute for Research on Labor and Employment (2020). Workers and learners during a global pandemic and social uprising (September). Online at https://www. labor.ucla.edu/wp-content/uploads/2020/09/Workers-and-Learners-during-a-Global-Pandemic-and-SocialUprising-1.pdf. Accessed 28 Sept 2020.

Urevich, R. (2019). Mark Janus wants his union dues back, American Prospect (July 11). Online at https:// prospect.org/justice/mark-janus-wants-union-dues-back/. Accessed 28 Sept 2020.

Verges, J. 2020. Here's what St. Paul teachers are bargaining for. Twin Cities Pioneer Press (March 10). Online at https://www.twincities.com/2020/02/19/st-paul-teachers-take-strike-vote-thursday-heres-what-theyrebargaining-for/. Accessed 21 Sept 2020.

Wasser, M. (2016). Making the case for union membership: The strategic value of new hire orientations. Online at https://www.jwj.org/wp-content/uploads/2016/09/JWJEDU_BestPractice_Report_2016_FINAL.pdf. Accessed 19 Sept 2020.

Yan, H. (2018). Here's what teachers accomplished with their protests this year. CNN (May 29). Online at https:// www.cnn.com/2018/05/29/us/what-teachers-won-and-lost/index.html. Accessed 24 Sept 2020.

Publisher's Note Springer Nature remains neutral with regard to jurisdictional claims in published maps and institutional affiliations. 